\title{
Surrounded by White Water: Conflicts in Management Sciences Regarding Truth and Reality
}

\author{
Ernie Stark \\ Bellevue University \\ Paul Stepanovich \\ Southern Connecticut State University \\ Paul Poppler \\ Bellevue University \\ Pamela J. Hopkins \\ Southern Connecticut State University
}

\begin{abstract}
This paper addresses two academic perspectives having different implications for management scholars. The first reflects the thinking of an empiricist or positivist, a perspective familiar to graduates of schools of business in universities throughout North America. The second represents postmodernism, a perspective familiar to social scientists but most likely foreign to graduates of schools of business in North America. This paper speculates on how differing assumptions about the nature of truth and reality can be used to interpret a hypothetical dilemma faced by two management scholars invited to respond to a perplexing situation facing a business executive. Further, this paper brings to management scholars a debate that has raged with force for decades across the social sciences and places that debate within a framework not unfamiliar to management scholars.
\end{abstract}

\section{Conflicts in Management Science}

Debate and conjecture surrounding management research (whether it be about corporate strategy, human resources management, or accountancy) focuses on what is presupposed about truth and about how one goes about determining whether or not something is true (Johnson \& Duberley, 2005). By tradition, management scholars in Occidental colleges of business are well grounded in the philosophy and approaches of scientific empiricism. Problem identification, modeling, quantification, cost/benefit analyses, and objective decision-making are staples of both undergraduate and graduate business degrees. An alternative perspective, postmodernism, has found frequent expression in some of the disciplines in the social sciences and humanities (e.g., philosophy, psychology, art, and cultural studies), but management scholars are increasingly finding themselves confronted by advocates of this emerging new perspective when interpreting, modeling, and solving organizational challenges. Metaphorically, a sort of white water tumult is evident in the differences, with an agreed upon approach much in doubt. 
Postmodernism remains notoriously difficult to define, as noted by Johnson and Duberley (2005), and at first sight can appear to be, as charged by many management scholars, a multiplicity of perspectives which emphasize ambivalence and indeterminacy. If the principles of science are the keystone to defining modernism, then postmodernism can be understood as a rejection of the primacy of the scientific method. The roots of postmodernism extend backward to a movement that emerged in the early $20^{\text {th }}$ century amongst artists and writers. The movement came to be known as "Dada" (Kruger, 2003b; Johnson \& Duberley, 2005). The essence of Dadaism was not to be found in art, but in the disgust expressed by the artist and writers of the movement. As objects of their disgust, the Dadaist raged against logic (referring to it as a dance of the creatively impotent), raged against every social hierarchy and equation established for the sake of values, and raged against knowledge, more precisely, the belief that anything could be known (Dickery, Doherty, \& Kriebel, 2005). To many at the time, the Dadaists appeared intent on promulgating confusion and wonder (Kruger, 2003b), and their art was characterized by randomness, anarchy, and fragmentation (Johnson \& Duberley, 2005).

Somewhat imbued with the values of this earlier movement, today's postmodernists approach management sciences by rejecting any claim that it is possible to develop a rational and generalized basis of scientific inquiry that explains the world from an objective standpoint (Johnson \& Duberley, 2005). When engaged in management research, the postmodernist's objective is not to get it right, but to challenge existing assumptions, meanings, and relations (Alvesson \& Deetz, 1996), and there is little doubt that postmodernists are impacting the debate regarding the essence of management science.

Elsbach, Sutton, and Whetten (1999) argued that whereas in traditional management research a good theory in 1989 required dependent and independent variables, in 1999 it was a trivial truth that such was not necessary. They continued by noting that in 1989 the notion that there is no objective means of assessing the value of a theory would have been viewed as heresy in many of the same corners that it is now accepted as a given truth, or at least a plausible and troubling possibility. Weick (1999) suggested that at least half of the players in management research are just beginning to grasp the messages of postmodernism (p. 797) which is to stop attempting to systematically define or impose logic on events and actions occurring within a business environment and recognize the limitations of scientific inquiry in the guise of management research (DeCock, 1998).

"We cannot erase the unsettling that has occurred..." among management scholars as a result of the emergence of postmodernism (Elsback, et al., 1999, p. 665), and this motivated Calas and Smircich to proclaim: "We are all effects and producers of the postmodern, and it is showing" (1999, p. 666). This unsettling is readily evident in the strong reaction to postmodernism from scholars of an empiricist and positivist inclination. Kruger (2003a) openly rejected the postmodern perspective by observing that rather than being concerned with the reduction of uncertainty, the generation of knowledge, and the search for truth, postmodernists champion the notion that 
arguments about reality are futile and that nothing can be certain. While Kruger acknowledged that there are many ways to make sense of a human phenomenon, he argued that postmodern contributions to management research are highly questionable because postmodernists refuse to make predictions about the phenomenon they observe (2003b). This may have been the motivation behind Haig's (2003) adamant warning to scholars to be cautious in their embrace of postmodernist research.

Edwin Locke (2002) was vigorous in his condemnation of postmodernism in academia. He argued that the fundamental, but not always acknowledged, goal of postmodernism is (and has always been) to promote skepticism and to replace the objective pursuit of knowledge with language games. He warned that the champions of postmodernism do not want to hold a mirror to the world, but rather want to liberate scholars from reality and leave them in a fantasy world, but as Ashkanasy (2007) noted, the question arises: Liberate scholars from whose reality?

\section{Purpose of this Paper}

The purpose of this paper is two-fold. First, it revives and continues the debate regarding philosophical foundations in management science. Second, whereas there is often a tendency toward abstraction in philosophical debates, our purpose is to bring the debate to a practical and meaningful level, specifically, the implications of two competing perspectives for decision-making in the business world. The next section in this paper presents each camp's perspective of truth and reality regarding management science. Then comes a hypothetical scenario wherein two management scholars, an empiricist and a postmodernist, advise a CEO about a real world business problem, and that is followed by a hypothetical critique of each scholar's advice from the perspective of the opposing camp. In conclusion, the authors discuss what they believe are critical issues implicit in this paper.

\section{On Being an Empiricist}

The empiricist starts with the premise that there is an independent external reality (ontology) that can be known (epistemology). The empirical method (also known by various monikers such as realism, positivism, and objectivism) of arriving at knowledge of the human condition in the workplace has a characteristic that recommends it: selfcorrection. Using this method of knowing requires that the self-correcting checks be anchored, as much as possible, in a reality lying outside the individual's personal beliefs, perceptions, biases, values, attitudes, and emotions. The best word to describe this reality is objectivity. Objectivity refers to those statements about the world that we currently can justify and defend using the standards of argument and proof employed within the community to which we belong (i.e., those of similar and like-minded training). This method of knowing about the human condition is most desirable because it appeals to evidence (specifically, propositions that lend themselves to scientific testing) (Indick, 2002). Indeed, a concern for the primacy of the empirical perspective appears to have been the motivation behind Rousseau's (2006) presidential address to the Academy of Management in which she challenged her colleagues to coalesce around 
what she termed Evidence-Based Management where decisions supported by the best available scientific evidence are give greater credibility than those argued from personal preference and unsystematic experience. Noting that Drucker is credited with observing that most business issues are generic repetitions of familiar problems cloaked in the guise of uniqueness, Rousseau and McCarthy (2007, p. 84-85) advocate that management issues should be addressed in an empirical manner whereby underlying dynamics are exposed and evidenced-based principles guide the choice of effective action.

In a grand sense, the primary goal of empiricism is to describe the reality of human social interactions and functions in the workplace by reflecting upon and testing theory (Kerlinger \& Lee, 2000). The empiricist acknowledges that reality may indeed be multilayered (Agnew \& Pyke, 1987), but values the contention that this reality can be grasped independently without occupying any particular biasing standpoint. The empiricist does not merely seek to accumulate facts about an observational checkpoint surrounded by regions of uncertainty (Agnew \& Pyke, 1987), but the empiricist also generates new theories that reflect the reality of the human experience (Kerlinger \& Lee, 2000). The empiricist seeks to create and use methods to control and eliminate factors that would weaken the ability to discover the true shape of reality (Kerlinger \& Lee, 2000). Reality of the human condition in the workplace becomes apparent when the area of uncertainty about a relationship between antecedents and ensuing human behavior is reduced to a point where prediction of human behavior in the presence of given antecedents is possible beyond the area of uncertainty attributable to random chance (Agnew \& Pyke, 1987). Stated more succinctly, empiricism operationalized as decisions based on evidence provides managers with a mindful and systematic way of diagnosing cause-and-effect relationships that enable practices to reliably yield desired results (Rousseau \& McCarthy, 2007).

Finally, systematic and standardized measurements assume great importance to the empiricist. Empiricists conduct their measurements such that they can be independently verified by others of similar training and knowledge through the process of replication, and this principle is violated if others dispute the measures and findings (Nunnally \& Bernstein, 1994). The process of quantifying observations provides the empiricist with numerical results believed capable of communicating reality in finer detail than personal judgments about human behavior in the workplace (Agnew \& Pyke, 1987).

\section{On Being a Postmodernist}

As previously noted, postmodernism is notoriously difficult to pin down, but this paper will follow Johnson and Duberley (2005) in their positioning of postmodernism as ontologically denying an independently existing reality. Since there is no independently existing reality to know, all that remains are subjective, relative knowings. Therefore, Johnson and Duberley (2005) in citing Berg (1989) observed that from a postmodern perspective it is not important if a statement about a management issue is true or false, but more important is if the statement is accepted, saleable, or valid for a larger audience. Why? At the heart of the postmodernist's growing challenge to empiricism is 
the argument that humans construct reality rather than discover it. Therefore, the important issues and the dialogues that surround reality in management science need to address the process of construction and the motives behind the construction of reality because this enables numerous perspectives (e.g. interpretivism, feminism, deconstructionism, etc.) to flower (Schultz \& Hatch, 1996).

Four assumptions anchor the postmodernist's approach to management science. The first critical assumption held by postmodernists is that of socially constructed, valueladen truths. For the postmodernist, the independent objective reality of the empiricist does not exist because the observer and the observed are intimately and inextricably interdependent due to the rules of interpersonal culture that people use to shape their reality. Such rules consist of linguistic conceptions shared among a community that are defined by the very act of that sharing, and there may be as many conceptual realities as there are cultural communities in which a particular concept exists. Which management concepts most accurately represent reality and are, therefore, more desirable are moot questions because the notion of correctness as a representation of objective truth is an illusion held by the empiricist and rejected by the postmodernist management scholar (Lefkowitz, 2003).

The second assumption is that understanding of the human condition consists of achieving meaning (Lefkowitz, 2003), and achieving meaning implies the act of interpretation through the process of hermeneutics. The hermeneutic enterprise enables meaning by discovering and interpreting the motives, beliefs and intentions forming the rules that govern human behavior in the workplace. Such rules can only be understood adequately from the internal perspective of the individual actor, not that of a detached observer as argued by the empiricist (Alvesson \& Deetz, 1996; Lefkowitz, 2003). Thus, within management science, one should seek meaning and interpretation rather than truth.

The third assumption of the postmodernist perspective is the importance of language. For the postmodernist, the most important rules that govern human behavior in the workplace are those having to do with language (Lefkowitz, 2003). Language is not used to describe the human condition; language creates the human condition. The world we live in and experience is a product of language, and as Ford (2001) observed, not only does language describe, but it also creates the very object in the description. Ford further suggested that organizations might not be mechanistic, political, or even organic, but they may be nothing more than simply linguistic constructions. As such, the postmodernist entertains no interest in any approach to management science that claims to result in a progressive accumulation of knowledge, but seeks instead to deploy his/her skills to unsettle and reconstitute language in such a manner as to undermine orthodoxy and tradition and give voice to what is unsaid, left out, or generally forgotten in discourses about the human condition within the workplace (Gergen, 2001).

The fourth assumption underlying the postmodernist's approach to management science has to do with power. To the postmodernist, any claim by the empiricist to 
detached reason and objectivity serves to mask the fact that their discourse bestows upon them the power to dominate and oppress those they observe in the workplace (Johnson \& Duberley, 2005). That is, as a result of the empiricist's claim of scientific knowledge in the presence of people lacking a socially legitimate claim to such knowledge, power is granted to a select group of management scholars to influence management practices used to ultimately regulate the behavior of those in the workplace and suppress the articulation of alternative perspectives. Thus, to the postmodernist, management science must focus on illuminating who has power, the language they used to legitimate that power, and how that power oppresses others in the workplace.

So, the strong and virulent response of empiricists to the increasing challenge of postmodernists management scholars mentioned earlier in this paper should not be unexpected given that the empiricist camp believes itself to represent a true philosophy (i.e., a process involving rational investigations of truths and principles of being, knowledge, or conduct) and argues that the same cannot be unequivocally said about postmodernism because it rejects at least two premises of rationality: the reality of collectively-reasoned descriptions of objects and their respective measurements. Believing itself to represent a philosophy of management science, empiricism not only argues that it is engaged in critical study of basic principles and concepts with a view to improving them or reconstituting them but also argues that postmodernism cannot

\section{Table 1. Summary of Viewpoints}

\begin{tabular}{|l|l|l|}
\hline \multicolumn{1}{|c|}{ Empiricism } & \multicolumn{1}{|c|}{ Postmodernism } \\
\hline $\begin{array}{l}\text { Nature of } \\
\text { Truth }\end{array}$ & $\begin{array}{l}\text { An independent and external reality } \\
\text { exists. }\end{array}$ & $\begin{array}{l}\text { No independent or external reality } \\
\text { exists. }\end{array}$ \\
to know. & $\begin{array}{l}\text { Objectivity: separation of the } \\
\text { observer from the observed. }\end{array}$ & $\begin{array}{l}\text { No ŅruthÓ बists, only meanings and } \\
\text { interpretations that are themselves } \\
\text { dependent on construction and } \\
\text { context; any Nonthós relative. } \\
\text { Subjectivity: observer becomes } \\
\text { immersed in the observation and } \\
\text { integrated with the observed. }\end{array}$ \\
\hline Method & $\begin{array}{l}\text { Scientific evidence; self-correcting; } \\
\text { falsification of theory. } \\
\text { Quantitative models emphasizing } \\
\text { logic and reason; systematic, } \\
\text { standard measurement. } \\
\text { Valueless: value-neutral, bias free, } \\
\text { and neutrality of power }\end{array}$ & $\begin{array}{l}\text { Phenomenological (meaning), } \\
\text { language games. } \\
\text { Qualitative models emphasizing } \\
\text { narrative, drawing, interviews, and } \\
\text { multiple perspectives. } \\
\text { Valueful: value-laden, biases } \\
\text { accepted, power infused by the } \\
\text { observed. }\end{array}$ \\
\hline $\begin{array}{l}\text { Desired } \\
\text { Outcomes }\end{array}$ & $\begin{array}{l}\text { Truth: prediction of human behavior } \\
\text { beyond random chance. }\end{array}$ & $\begin{array}{l}\text { Voice: empowerment, disruption, } \\
\text { destabilization, de-centering, fluidity, } \\
\text { and pluralism. }\end{array}$ \\
\hline
\end{tabular}


assume this distinction because, by definition, it does not acknowledge that improving, reconstituting, or even confirming principles or concepts is even possible. From the perspective of the empiricist, postmodernism is most appropriately understood as an ideology forming the basis of a particular political mindset. Of course, from the perspective of the postmodernist, the philosophy of the empiricist is just another, albeit privileged, system of belief. Table 1 presents a summary of the competing views.

\section{Surrounded by White Waters: A Case in Point}

How might these competing perspectives manifest themselves when management scholars bring their convictions into contact with business problems? The following hypothetical case is loosely constructed on an incident reported by Thomas (2000) and advanced as a possible scenario for investigating this question. The Vice President (VP) of Human Resources in a medium size business firm in a Midwestern state returned from an annual conference of the Society of Human Resource Management. Inspired by a presentation, the VP approached the Chief Executive Officer (CEO) with a proposal to institute a week-long company awareness campaign about "Violence Against Women" at a projected cost of $\$ 50,000$ (a considerable sum for a medium size business organization). The VP justified the cost on the following assumptions: 1) women comprise the majority of employees in the firm, 2) women are disproportionately victims of violent acts, and 3) men must be made aware of and sensitive to behaviors that lead to acts of violence against women in U.S. society.

The CEO advanced the request to the executive team for input. After some review and reflection, the Chief Operations Officer (COO) objected and argued that census statistics suggested that men, not women, were overwhelmingly the target and victims of violent acts within the U.S. Further, there was no readily apparent knowledge of workplace acts of violence against the firm's female employees. When presented with the COO's argument, the VP of Human Resources responded that such facts were irrelevant to the situation because females sense that they are at risk of suffering violence given their gender. Thus, the expenditure would lower the anxiety of female employees and result in improved job satisfaction and performance. The COO countered that an expenditure of $\$ 50,000$, given the current high price for energy facing the firm, would be more justified if directed toward purchase of software that would enable improved planning for efficient operations and production.

Even though it is reasonable to assume that the CEO would be comfortable with making decisions in ambiguous and complex environments and that a decision here would be no different, our scenario has the CEO seeking consultation from two eminent human resource scholars from a nearby university: one grounded in empiricism and one grounded in postmodernism. The hypothetical actions that follow are intended to reflect, as closely as possible, how the underlying principles espoused by each camp would translate into construction of a response to the CEO's request. 


\section{Advice From The Postmodernist}

The postmodernist's advice is guided by reality construction, legitimating of power, and societal values. In discussions with the CEO, the postmodernist management scholar encouraged the CEO to examine the realities created by his employees and the executives. Indeed, the CEO was encouraged to examine his own reality-making process and the realities thus created. The postmodernist emphasized that reality, as much as the CEO might disagree, is, and can only ever be, an internal representation, a perception complete with deletions, distortions and generalizations. A case was made that numerous philosophers emphasize, and most neuroscientists confirm, that we can never "know" an external reality directly. All sensory inputs are converted to electrical impulses before being massaged by the limbic system and neocortex (see LeDoux, 2002, Ch. 5). The reality we know is a creation and, at best, a representation of an external reality, if it exists at all.

For the postmodern management scholar, the challenge facing the CEO had little to do with determining if justification existed for the expenditure requested by the VP of Human Resources regarding an awareness campaign focusing on violence against women; rather, the challenge for the CEO is to come to grips with the meanings underlying the request and any potential response to that request. The postmodernist scholar stressed to the CEO the importance of exploring the meanings created by the workers, the VP of Human Resources, and the COO. These meanings are based on individual histories and realities that have been created over time. The histories are influenced by, among other things, socio-economic status, race, and gender. These meanings, in turn, influence present views and expectations, which over time have likely been reinforced by selective perception and past reality creation - self-fulfilling prophesies. In short, the CEO was encouraged to consider that each reality is complex and unique.

These realities are not only unique to each person but interact with others for form highly complex networks of realities. The postmodernist scholar encouraged the CEO to appreciate the differences among individually constructed realities and to explore the complexities not only within each individual construction but also among individuals. As such, the postmodernist management scholar did not recommend conducting an employee survey on the subject; rather, the scholar encouraged interviews and observations of an ethnographic nature that recognize and appreciate the complexities of reality creation. Such qualitative and subjective information were judged critical to the CEO's decision, and in-depth interviews were encouraged to explored the complexities, feedback loops, biases, and uniqueness of players as well as the consultant's own biases. Further, special attention was paid to the language used by all concerned as language creates the realities within the firm.

The second area of concern for the postmodernist management scholar was power: Who has it? How did they attain it? What are they doing with it? Since institutions (business organizations included) are social constructions, then they were constructed by some group for some purpose. While there were likely issues of power present in this 
company relating to race or economic position, the focus was on the issue of gender. Regarding power, the postmodernist management scholar was well aware that women have been marginalized in both our culture and, subsequently, in business organizations and that they are, therefore, disenfranchised. (While not clearly stated, given the general absence of females at higher levels of business organizations, it is not an unreasonable assumption that the $\mathrm{CEO}$ and $\mathrm{COO}$ were male, and in this scenario it is known that most of the employees were women.) Given these conditions and parameters, the postmodernist management scholar confronted the CEO regarding the traditional power of masculinity to determine questions regarding what is needed to be known and the process of moving from the unknown to the known in a certification process. The CEO was guided to an awareness that feminist scholars are challenging the assumptions underlying the traditional male approach to problem solving by pointing out that women start with inclusion, reception, and acceptance; they start with the individual's knowledge and honor experience (Belenky, Clinchy, Goldberger, \& Tarule, 1986; Calas \& Smircich, 1996), a much different process than associated with males. In short, the CEO was challenged to rethink the influence of the firm's power structure in arriving at a decision regarding the request of the VP of Human Resources.

The third area of concern for the postmodernist was that of social values, however constructed. If there is no external objective reality (Truth) to arbitrate differences of construction, then a way to decide is needed. Since truth is not possible, then it will come down to values such as good and right. Since opinions will differ, then dialogue is unavoidable. In this case, the grand narrative (theory) open to challenge was the profit motive. In discussions with the CEO, the postmodernist scholar expressed not as great a concern for the financial implications of the VP's request as with a concern for decentering, challenging accepted wisdom, pluralizing, and providing voice. The objective was to disrupt the CEO's comfortable and traditional perspective.

After consideration of the above, the advice of the postmodernist management scholar was to spend the resources to conduct the awareness campaign and in the process explore meanings being constructed across the firm. Doing so, it was reasoned, would send a message to women in the organization that they are valued. On the surface and in the short term, the campaign would likely be humanizing, encouraging equity and empowerment. On a deeper level, the postmodernist scholar strongly advocated for the freedom among the disenfranchised necessary to raise consciousness about issues of power, and, in general, to encourage choice and freedom where now choice and freedom were constrained among the disenfranchised female workers. This decision and future consultation, it was claimed, would provide an opportunity to increase a sense of social awareness motivating other desirable changes.

As so described, it appears as though the postmodernist management scholar has taken a stance, something some critics claim is contrary to the postmodern belief. However, the postmodernist's concern for relativity and subjectivity lays not so much in not taking a stance as it does in breaking up fixed positions, de-centering, and in keeping things fluid and open. This, not necessarily increased productivity or profits, is the criterion by which the postmodern management scholar would determine the 
success of the consulting engagement.

\section{Advice from the Empiricist}

The empiricist management consultant is faced with an overriding concern: "How does one achieve true knowledge of the human condition?" More specifically in this scenario, the concern is with the reality of the human condition within the aforementioned firm. The advice to the CEO in this hypothetical scenario reflects the empirical perspective of Kepner and Trego (1981) who advocated that management decisions must utilize rational thinking: a conscious use of an approach expressed in simple, common language that refers to those statements about the world that we currently can justify and defend employing communal standards of argument and proof. In short, management decisions must appeal to evidence (Rousseau \& McCarthy, 2007). The empiricist management scholar brought to this case a perspective that rational and linear thinking constitutes a set of tools for getting things done, for handling information productively so that problems are solved and successful decisions made.

The empiricist scholar began by advising the CEO to construct a rational and systematic process for establishing the true nature of the phenomenon of violence against women in the firm independent of any biases that might be held by the CEO. As a first step, the CEO was advised to seek out documentable data that violence against women constituted a problem of concern for the company and its stakeholders (both internal and external). This first step implied searching for factual evidence of violence against women directly employed by the company or against women associated with the company. If no such evidence existed, the empiricist scholar advised the CEO to require of the VP of Human Resources a stronger case for expenditure of organizational resources on such a campaign beyond the fact that violence against women was a topic of discussion at a conference of human resource professionals.

"What if documental evidence suggested that a problem with violence against women did exist with in the company?" asked the CEO. The empiricist management scholar responded that the CEO should then seek to establish the magnitude of the problem. The CEO was advised to determine at that point if the evidence indicated that violence against women was of such magnitude that it either represented a direct threat to the health and safety of a sizable number of female employees or that the phenomenon would ultimately impact the financial performance of the firm in a negative manner. As an empiricist, the management scholar argued for establishing some measurable criterion against which the evidence might be dispassionately evaluated. If the magnitude of evidence did not meet the criteria, the CEO was advised to call upon the VP of Human Resources to present a rational case as to why the company should invest $\$ 50,000$ in a phenomenon that apparently was of little magnitude or had no direct negative impact on the company's return to its stakeholders. The COO's argument for allocating the $\$ 50,000$ for software to enhance the efficiency of operations should not, counseled the empiricist scholar, be easily dismissed. 
If, to an unprejudiced observer, it became apparent that violence against female employees existed and that it was of such a magnitude that it represented a direct threat to the health and safety of a sizable number of female employees or it ultimately influenced the financial performance of the firm, the empiricist scholar counseled the CEO to examine the evidence at that point to determine the place and time associated with the acts of violence against women. That is, were the violent acts occurring at work and on company property, or were the violent acts generally domestic in nature? If such violent acts were occurring at the workplace, the empiricist management scholar stated unhesitatingly that the CEO and the management team must take immediate action to ensure a safe and secure working environment for its female employees. If, on the other hand, the violent acts were domestic in nature and occurring away from the workplace, the empiricist scholar counseled the CEO to reflect on the company's social responsibility policy and consider if it created an imperative to respond to violence against women within domestic settings.

Should progression through the above steps lead to the conclusion that responding to violence against women is an imperative that the company must address, the empiricist management scholar advised the CEO to determine if the $\$ 50,000$ expenditure for an awareness campaign constituted the most reasonable action for alleviating the problem. More specifically, the empiricist scholar recommended that faced with such an imperative the CEO establish the outcomes that must be achieved from any expenditure by the company to address this problem. Along these lines, the CEO was advised to identify additional outcomes that would be highly desirable but not necessarily critical to determining the success of the company's response and weigh these non-critical outcomes to reflect their level of desirability. Finally, the empiricist management scholar recommended that the CEO generate at this point competing avenues for addressing the violence against women problem (e.g. firing of perpetrators, enhancing security on company premises, increasing efforts to lobby for social legislation, etc.) and proceed to eliminate those avenues that could not rationally be expected to produce the must be achieved outcomes previously identified. Selecting a course of action from the remaining alternatives would require the CEO to evaluate each against the weighed desired outcomes and determine the course of action with the greatest potential for achieving the most desirable outcomes.

In summary, the advice given to the CEO reflected the empiricist's underlying concern for the reduction of uncertainty, the generation of knowledge, and the search for truth. Without reference to objective facts and value standards, how are organizational decisions to be made and disagreements resolved? The empiricist seeks to steer clear of what is seen as nihilism implicit in postmodern perspectives by rejecting the contention that all organizational decisions reflect nothing but the arbitrary and subjective preferences of the decision-maker (Locke, 2003) and avoiding assignment of equal voice to diverse views in situations void of any basis for rationally discerning among their differential worth (Friedman, 2003). In short, as Rousseau and McCarthy (2007) concluded, an empirical perspective promotes management decisions based on evidence leading to the reduction of over use of ineffective practices and under use of approaches known to be effective. 


\section{A Critique of the Other's Approach}

Now, in this scenario, the CEO has received advice representing two competing perspectives of equally esteemed management scholars (see Table 2). However, seeking more information from which to make the final decision, the CEO returned to each scholar and asked for a criticism of the other's approach to addressing this situation.

Table 2. Summary of Advice to the CEO

\begin{tabular}{|l|l|l|}
\hline Method & \multicolumn{1}{|c|}{ Empiricism } & \multicolumn{1}{c|}{ Postmodernism } \\
\hline & $\begin{array}{l}\text { Objectively verify the assumptions } \\
\text { as true, seek scientific evidence, } \\
\text { and employ quantifiable } \\
\text { measures. } \\
\text { Use rational, quantifiable decision } \\
\text { processes to identify and evaluate } \\
\text { alternative courses of action. }\end{array}$ & $\begin{array}{l}\text { Conduct interviews to explore } \\
\text { meanings, value and power } \\
\text { relationships. } \\
\text { Focus on the process of reality } \\
\text { construction, the use of language, } \\
\text { and the legitimization of power. }\end{array}$ \\
\hline Recommendation & $\begin{array}{l}\text { Spend the } \$ 50,000 \text { only if it is } \\
\text { objectively justified and } \\
\text { demonstrates a potential cost- } \\
\text { benefit advantage. }\end{array}$ & $\begin{array}{l}\text { Spend the } \$ 50,000 \text { as an } \\
\text { investment in the social good. }\end{array}$ \\
\hline Outcome & $\begin{array}{l}\text { Optimization of shareholder } \\
\text { return. }\end{array}$ & $\begin{array}{l}\text { Empowerment, voice, de- } \\
\text { centering, and disruption of current } \\
\text { realities. }\end{array}$ \\
\hline
\end{tabular}

\section{Empiricist on the Postmodernist's Advice}

The critique of the postmodernist's advice to the CEO by the empiricist management scholar reflected Kruger's (2003b) argument that whereas empiricists are concerned with simplification and comprehension of information, postmodernists are interested in the elaboration of ideas and even obfuscation. The empiricist scholar concluded that any objective pursuit of knowledge regarding the decision to spend or not to spend the $\$ 50,000$ had been replaced in the advice the CEO received from the postmodernist scholar with language games and promotion of a political/social ideology currently in vogue. The empiricist scholar justified this conclusion by citing Locke's (2002) observation that all that postmodernism offers to management science, by its own admission, are word games that lead nowhere and achieve nothing. In short, the empiricist scholar viewed the recommendations of the postmodernist management scholar as so fundamentally flawed, so devoid of rationality, and so inapplicable to the 
situation facing the CEO as to make impossible a decision yielding an effective outcome.

\section{Postmodernist on the Empiricist's Advice}

The postmodernist scholar charged that empiricist scholar wanted to study the issues in order to make an informed, dispassionate, and rational decision, and this is simply not possible. The facts used to provide evidence to the empiricist scholar, it was argued, are based on methods that stem from an overarching theory, the assumptions for which cannot be proven. What is a fact? Who decides which facts get counted, get included, get dismissed, etc. (Baack, 2007)? In addition to being impossible, the empirical approach, argued the postmodern scholar, objectifies actors in its presumption that an objective and independent view is possible. What the empiricist management scholar advised doing in this case, argued the postmodernist scholar, is cold, calculating, and dehumanizing. The actors here are reality-constructing employees who should be afforded the dignity of participating in and contributing to the construction of the reality proffered by the empiricist consultant. Further, observed the postmodernist scholar, the linear, rational, quantifiable optimization of cost/benefits employed by the empiricist consultant is a reflection of the masculine mind, and ignores the feminine. Should one question the impact on the minds and hearts of the female workers where decisions that affect them are being made with a cognitive process that is alien to them?

Another major concern of the postmodernist with the empiricist's advice was the emphasis on measurable outcomes in general and financial outcomes in specific. The postmodernist scholar pointed out that many dimensions of the quality of workplace life cannot be quantified or expressed in monetary value. Many, if not most, of these are as important as immediate financial outcomes, but they cannot be easily factored into the calculus of business decisions (see Gioia, 1992 for a personal account of implications).

In summary, postmodernists eat, drink, and drive cars, and play the reality game, a game for which someone made the rules and the rules favor some over others. Postmodernists keep this view in the forefront of their thinking, but empiricists, on the other hand, tend to accept the rules as given, as laws of nature. Postmodernists consider this questionable in the natural sciences and dangerous in the management sciences. In addition, empiricists view science as value-neutral. That is, the results are neither advanced for their goodness or badness, but for their validity and reliability (Kerlinger \& Lee, 2000). Postmodernists disagree. Since both the scientific method and the laws discovered by this process do not exist out there but are created actively and constantly by man (literally), then they are not valueless. This is why the postmodernist scholar vigorously challenged the CEO to confront and address the issue of values in this scenario: What is right, just, and fair? Who wins, who loses, and why?

\section{Discussion}

The authors of this paper did indeed act as advocates of the two competing perspectives of management science and discussed herein. Was it fair of them to 
structure the two opposing camps in this paper in such starkly contrasting terms, and might there be a middle ground that they are overlooking? Perhaps, but while the authors are peers and colleagues with great respect of the others' accomplishments, they are none-the-less inclined out of deep conviction to forcefully challenge and dispute the underlying principles from which the other approaches management science and education. While scholarly tolerance suggests some middle ground, the authors are not necessarily accepting of the legitimacy of the others' approach. However, all agree that the following issues evolving from this paper merit further deliberation by management scholars.

First, is it appropriate to question the mantle of "management science" proudly proclaimed by the majority within most Occidental colleges of business? That is, how confident should one be that the rational investigations embraced by empiricists who have traditionally constituted the majority are generating truths and principles of being, knowledge, or conduct in the field of management? Postmodernist charge that rather than representing an accumulation of knowledge that has been repeatedly tested and verified over the years, trumpeted outcomes of management science are merely artifacts of a history of unquestioned distribution of power toward this majority and reflected throughout colleges of business in the Western world. On the other hand, what should be made of the postmodernist claim that there is no objective truth to be grasp in the study of management, only an understanding and appreciation of competing meanings that individuals and groups attach to a phenomenon? More precisely, in the absence of any pretense for finding underlying principles, overarching theory, or getting things right, does the postmodernist perspective offer anything more beneficial to the study of management than a deeply felt advocacy for linguistic processes wherein reality can never be verified?

Second, as noted by Elsbach et al. (1999), postmodernism is making inroads across colleges of business where the nature of management education has traditionally reflected a Western predisposition for the empirical perspective, but is there a value to be gained from accelerating efforts to interject a postmodernist perspective into management education? The underlying assumption of management education in most colleges of business is that it represents an accumulation of knowledge whose truth has been validated and tested absent any bias and is therefore worthy of transmission to a larger audience. Given the postmodernist mission of undermining such authority by pointing to how notions of truth, objectivity, facticity, and science are merely discursive or linguistic constructs, Johnson and Duberly (2005) suggest that postmodernism has devastating implications for how one understands management and management practices. Not the least of these would be a focus on deconstructing what the science of management purports to know by seeking an understanding of the particular language games and the rules that produced such a consensus in the first place. While postmodernists would applaud this inevitability and argue that it will widen consideration of what is thinkable, knowable, and doable within the discipline, should one question the utility inherent in such an approach to management education when the beneficiaries upon graduation ultimately face the challenges accompanying the positions they accept in business and industry? 
Finally, management science and education is indeed being swept into turbulent white waters where issues such at those discussed in this paper are of the utmost importance, and the implications of this event are far reaching. For a management scholar to accept the postmodernist perspective is to reject the assertion that uncertainties surrounding questions of truth about the human condition in organizational settings can be reduced by rational and logical means to such a degree that outcomes can be predicted beyond that expected by random chance. In short, a postmodernist perspective would negate Rousseau and McCarthy's (2007) contention that management research and education should enable managers to use evidence in developing substantive expertise as opposed to faddish and unsystematic beliefs espoused by the management guru of the moment that produces erratic and unreliable results. For a management scholar to accept an empirical perspective is to reject the assertion that what appears as truth in management science is a social construct resulting from the language used to describe the phenomenon under study. That is, while the empirical perspective may acknowledge that truth is often multi-layered in the study of management and cause-and-effect relationships complex, it would avoid at all costs the postmodernist propensity for assigning equal voice to diverse views and competing meanings when a situation lacks any basis for rationally discerning their relative value. Should the empiricist win-the-day and "protect the bastion" in the battle for focus in management science and education, organization decision-makers seeking scholarly consultation such as the CEO in our scenario will likely continue to give credence to advice from those most successful at reducing uncertainty and enabling achievement of predictable results. On the other hand, should the postmodernist winthe-day and "storm the bastion" (or even continue their modest inroads), implies that such organization decision-makers will increasingly come into contact with those intent on revealing the multitude of realities that exists within an organization, undermining orthodoxy, challenging tradition, and giving voice to what is unsaid, left out or generally forgotten.

\section{References}

Agnew, N. M., \& Pyke, S. W. (1987). The science game: An introduction to research in the social sciences. Englewood Cliffs, NJ: Prentice Hall.

Alvesson, M., \& Deetz, S. (1996). Critical theory and postmodernism approaches to organizational study. In S.R. Clegg, C. Hardy, \& W. R. Nord (Eds.), Handbook of organizational studies (pp. 191-217). London: Sage.

Ashkanasy, N. M. (2007). From the editor: Evidenced-based inquiry, learning, and education: What are the pros and cons? Academy of Management Learning and Education, 6, 5-8.

Baack, S. (2007). A review of Pfeffer and Sutton's "Hard facts: Dangerous half-truths, and total nonsense: Profiting from evidence-based management". Academy of Management Learning and Education, 6, 139-141.

Belenky, M. F., Clinchy, B. M., Goldberger, N. R., \& Tarule, J. M. (1986). Woman's ways of knowing: The development of self, voice, and mind. New York: Basic Books. 
Berg, P. O. (1989). Postmodern management? From fact to fiction in theory and practice. Scandinavian Journal of Management, 5, 201-217.

Calas, M. B. \& Smircich, L. (1996). From the woman's' point of view: Feminist approaches to organizational studies. In S. R. Clegg, C. Hardy, \& W. R. Nord (Eds.), Handbook of organizational studies (pp. 218-258). London: Sage.

Calas, M. B. \& Smircich, L. (1999). Past postmodernism? Reflections and tentative directions. Academy of Management Review, 24, 649-671.

DeCock, C. (1998). It seems to fill my head with ideas: A few thoughts on postmodernism, TQM, and BRP, Journal of Management Inquiry, 7, 144-153.

Dickery, L., Doherty, B., \& Kriebel, S.T. (2005) Dada: Zurich, Berlin, Hanover, Cologne, New York, Paris. National Gallery of Art/DAP.

Elsbach, K. D., Sutton, R. I., \& Whetten, D. A. (1999). Perspectives on developing management theory, circa 1999: Moving from shrill monologues to (relatively) tame dialogues. Academy of Management Review, 24, 627-633.

Ford, J. (2001). Call for papers. Special topics forum: Language and organizations. Academy of Management Review, 26, 328-330.

Friedman, $\mathrm{H}$ (2002). Psychological neoscience in a postmodernist context. American Psychologist, 57, (6/7),462-463.

Gergen, K. (2001). Psychological science in a postmodern context. American Psychologist, 56, 803-813.

Gioia, D. A. (1992). Pinto fires and personal ethics: A script analysis of missed opportunities. Journal of Business Ethics, 11, 379-389.

Haig, B. D. (2002). Truth, method, and postmodern psychology. American Psychologist, 57, (6/7), 457-458.

Indick, W. (2002). Fight the power: The limits of empiricism and the costs of positivistic rigor. Journal of Psychology, 136, 16-21.

Johnson, P., \& Duberley, J. (2005). Understanding management research. Sage: London.

Kepner, C. H., \& Trego, B. B. (1981). The new rational manager. Princeton, NJ: Princeton Research Press.

Kerlinger, F. N., \& Lee, H. B. (2000). Foundations of behavioral research. Forth Worth, TX: Harcourt and Brace.

Kruger, D. J. (2002a). Postmodern parlor games. American Psychologist, 57, (6/7), 461.

Kruger, D. J. (2002b). The deconstruction of constructionism. American Psychologist, $57,(6 / 7), 456-457$.

LeDoux, J. (2002). Synaptic self: How our brains become who we are. New York: Penguin Books.

Lefkowitz J. (2003). Ethics and values in industrial-organizational psychology. Mahwah, $\mathrm{NJ}$ : Lawrence Erlbaum Associates.

Locke, E. (2002). The dead end of postmodernism. American Psychologist, 57, (6/7), 458.

Nunnally, J. C., \& Bernstein, I. H. (1994). Psychometric theory. New York, NY: McGrawHill.

Rousseau, D. M. (2006). Is there such a thing as "evidence-based management"? Academy of Management Review, 31, 256-269. 
Rousseau, D. M., \& McCarthy, S. (2007). Educating manages from an evidenced-based perspective. Academy of Management Learning and Education, 6, 84-101.

Schultz, M. \& Hatch, M. J. (1996). Living with multiple paradigms: The case of paradigm interplay in organizational culture studies. Academy of Management Review, 21, 529-557.

Thomas, J. (2000, October 8). Harkin vows to keep fighting for controversial nomination. The Omaha World-Herald, p. 18A.

Weick, K. E. (1999). Theory construction as disciplined reflexivity: Tradeoffs in the 90s. Academy of Management Review, 24, 797-806. 